\title{
The Invention of the Steam Engine
}

\author{
by Rochelle Forrester \\ Copyright (C) 2019 Rochelle Forrester \\ All Rights Reserved \\ The moral right of the author has been asserted
}

\begin{abstract}
Anyone may reproduce all or any part of this paper without the permission of the author so long as a
\end{abstract} full acknowledgement of the source of the reproduced material is made.

Second Edition

Published 30 September 2019

Preface

This paper was written in order to examine the order of discovery of significant developments in the history of the steam engine. It is part of my efforts to put the study of social and cultural history and social change on a scientific basis capable of rational analysis and understanding. This has resulted in a hard copy book How Change Happens: A Theory of Philosophy of History, Social Change and Cultural Evolution and a website How Change Happens Rochelle Forrester's Social Change, Cultural Evolution and Philosophy of History website. There are also philosophy of history papers such as The Course of History, The Scientific Study of History, Guttman Scale Analysis and its use to explain Cultural Evolution and Social Change and the Philosophy of History and papers on Academia.edu, Figshare, Mendeley, Vixra, Phil Papers, Humanities Common and Social Science Research Network websites.

This paper is part of a series on the History of Science and Technology. Other papers in the series are

\begin{tabular}{|c|c|c|c|}
\hline \multicolumn{4}{|c|}{ The Invention of Stone Tools } \\
\hline History of Metallurgy & \multicolumn{3}{|c|}{ The Development of Agriculture and Pastoralism $\quad$ History of Writing } \\
\hline The Invention of Glass & \multicolumn{3}{|c|}{ History of Astronomy Invention of Microscopes and Telescopes } \\
\hline History of Printing & \multicolumn{3}{|c|}{ The Discovery of Steam Power } \\
\hline Electric Telegraph & Telephone & Television & $\underline{\text { Motion Pictures }}$ \\
\hline \multicolumn{4}{|c|}{ Internal Combustion Engine $\quad$ Motor Car } \\
\hline \multicolumn{4}{|c|}{ The Discovery of the Periodic Table } \\
\hline
\end{tabular}

Other papers by Rochelle Forrester include works on Epistemology and the Philosophy of Perception such as Sense Perception and Reality and on quantum mechanics such as the Quantum Measurement Problem and The Bohr and Einstein debate on the meaning of quantum physics. Rochelle Forrester's work is also published on Slideshare, Issuu and Scribd. Rochelle Forrester is a member of the International Network for Theory of History. 
There were a number of conditions necessary for the invention of the steam engine. A vital one was the presence of a need, initially that of how to get water out of mines and later how to drive the new machinery that was being produced as part of the industrial revolution. But needs are common and they are not always met. The reasons why those needs were met was due to the scientific progress that was going on in 16th and 17th century Europe concerning the knowledge of atmospheric pressure, how to create vacuums and of the properties of gases. Allied to this scientific progress was a belief in Europe at the time that progress could be made and problems could be solved. The inventors at the time applied scientific knowledge to solving the problems that existed and after long periods of trial and error, including the development of new and better materials, were able to produce a working steam engine. Crucial to the progress made by the inventors was the diffusion of scientific and engineering knowledge which enabled them to build on each other's work. The earlier development of printing was important to the diffusion process and the role of organizations such as the Royal Society was also important.

The earliest human knowledge of the power of steam comes from the classical world when Heron of Alexandria described various machines using steam for such purposes as opening temple doors or to blow a horn. The engines were used to amuse or astonish rather than for practical or economic purposes. Claims have been made that the presence of slavery in Roman world ensured that the steam engine was not used in industry as slaves were a cheaper manual source of power. This argument can hardly be confirmed as we know little of the price of slaves and how much they cost to keep in classical times so we can hardly say that slavery made it uneconomic to develop an industrial steam engine. It may well have been that for long periods in the classical world slaves may have been expensive and a steam engine may well have been more economic than slaves especially for difficult jobs such as getting water out of mines. In any event it was impossible for the Romans to calculate the costs both for the development and manufacturing of a steam engine until they had actually produced one. The most likely reason the Romans never developed a steam engine was that the materials available were not strong enough or finely worked enough to allow an industrial steam engine and their lack of understanding of the principles of vacuums, atmospheric pressure and the properties of gas such as steam.

In the modern period from the Renaissance onwards the earliest attempts to harness steam power were toys or perhaps laboratory experiments similar to those Heron described in classical times. Such devices were produced by Giambattista della Porta (1536-1605) in Naples and Salomon de Caus (1576-1626) in England. It is not known whether either of these men knew of the classical steam engines described by Heron. The first sign of any attempt to use steam power for industrial purposes were patents taken out in 1631 by a prolific patentee David Ramsay "To raise water from lowe pitts by fire", "To make any sort of mills to goe on standing waters by continual moc'on without the helpe of windes, waite of horse", "To make boates, shippes and barges to goe against the wind and tyde." (sic) All these aims were eventually to be achieved by steam power, but only the first of them represented a pressing social need of the times. This was the problem that water was getting into mines and making the mining operations difficult or impossible. The extent of the problem can be seen in that, of 182 patents granted between 1561-1642, one in seven was for the raising of water. The details of Ramsay's patents are unknown and there is no evidence any machines were actually

\footnotetext{
${ }^{1}$ Dickinson, H W (1963) A Short History of the Steam Engine, Cass: London 185-186

${ }^{2}$ Rolt, L T C (1963) Thomas Newcomen, David and Charles: Dawlish, London, 20-21

${ }^{3}$ Ibid., 23

${ }^{4}$ Dickinson, H W (1963) A Short History of the Steam Engine, Cass: London 
produced. The first attempt to actually produce a large scale machine was made by the Marquis of Worchester in the 1660's but there is some doubt as to whether it was a genuine steam engine and in any event it was not a practical success. ${ }^{5}$ Worchester was followed by Sir Samuel Morland who described a steam engine in a book he wrote which may or may not have been the same machine mentioned in the diaries of a Roger North. Parliament seems to have been supportive of these inventors granting both Worchester and Morland a patent for their inventions, such as they were.

While this was happening in England, Evangelista Torricelli of Faenza (1608-1647), Blaise Pascal (1623-1662) and Otto von Guericke (1602-1686) engaged in a series of scientific experiments which showed the effects of atmospheric pressure and that if a vacuum could be created the weight of the atmosphere could be a useful source for the transmission of power. A further discovery relevant to the development of steam power was Boyle's Law which states the volume of a given mass of gas varies inversely with its pressure when its temperature remains constant. It is the pressure from the steam which lifts the piston, in post Newcomen steam engines, and as the volume of the steam increases in the cylinder as the piston rises its pressure falls allowing atmospheric pressure to force the piston back down. As the piston falls the steam pressure in the cylinder increases giving the steam its "spring" which then forces the piston back up. The Newcomen engine worked by a weight attached to a beam and which was attached to the piston and which caused the piston to rise. The piston would then be forced down when a vacuum was created in the cylinder under the piston, which would cause the piston to fall due to atmospheric pressure above the piston being greater than the pressure below the piston. A knowledge of Boyle's Law, how to create vacuums, and the effects of atmospheric pressure were crucial to the development of the steam engine.

Denis Papin (1647-1712), a French Huguenot refugee from Louis XIV's France, while in London working for the Royal Society, produced the first working model of a steam engine operated by atmospheric pressure. He placed water in a cylinder and lit a fire under the cylinder. The steam in the cylinder caused a piston to rise to the top of the cylinder and drive the air out of the cylinder. The fire was then removed, the steam condensed and a vacuum was created within the cylinder and the piston was driven down into the vacuum causing a weight attached to the piston to lift.

The first to come up with a practical working, although rather limited steam engine was Thomas Savery. He was from Devon, a fellow of the Royal Society, and was granted a patent for "rising water by the impellant force of fire". Savery's engine worked by steam alternatively entering two chambers and forcing water out. The steam is then condensed to create a vacuum which then draws more water into the chamber which is again forced out by the steam entering the chambers. Savery produced a practical steam pump capable of continuous operation but with the unfortunate defect of being unsuitable for pumping water out of mines as it could only pump water to a height of twenty feet, not enough to get water out of most mines. Furthermore the machine lacked a safety valve and was inclined to explode on occasion due to the pressure of steam on the boiler. Nevertheless Savery's engine was the first steam engine to be sold commercially.

The first really successful steam engine was that produced by Thomas Newcomen, who like Savery was from Devon. H. W. Dickinson comments that Newcomen's engine "was little more than a combination of known parts" with one or two additional ideas of Newcomen's added to it. Burstall considered Newcomen's engine

"came about as the culmination of a series of advances that had been made during the preceding two centuries and it is most likely that if Newcomen had not built the first engine of this kind someone else would have done so very soon afterwards; indeed Denis Papin very nearly did, for he was

\footnotetext{
${ }^{5}$ Rolt, L T C (1963) Thomas Newcomen, David and Charles: Dawlish, London, 24-25.

${ }^{6}$ Dickinson, H W (1963) A Short History of the Steam Engine, Cass: London 29-30
} 
experimenting with the condensation of steam in a cylinder, a few years earlier, but he was not a practical mechanic and he was defeated by the mechanical difficulties."

Another interpretation by L. T. C. Rolt is that:

"The wonder is not that Newcomen spent anything from ten to fourteen years on his invention before he achieved success but that such a staggering advance could have been made by one man in a lifetime. ... Seldom in the history of technology has so momentous an invention been developed by one man so rapidly to so definitive a form. When, in addition we remind ourselves of the, to us, unbelievably primitive means at Newcomen's disposal in 1712, then we can scarcely fail to regard his achievement with a wonder akin to awe."

Rolt does seem to go over the top in his admiration for Newcomen's achievement.

The Newcomen engine worked by using a weight attached to a beam to force a piston to rise. The piston would then fall due to a vacuum being created under the piston by the injection of water into the cylinder which caused the steam to condense, reducing pressure under the piston to a level below atmospheric pressure, which forced the piston down. The beam attached to the piston operated a pump, to pump water from the mine.

In the years following 1712 Newcomen's engines began operating in mines all over England and also in Scotland, Wales and in Hungary, France, Belgium and possibly in Germany and Spain. Later in the 18th Century, after a scientific study, various improvements were made to the Newcomen engines by John Smeaton which considerably increased their efficiency. An important reason for the success of Newcomen's engine over the Savery engine was that Newcomen's, was an atmospheric engine that did not need to use steam pressure any higher than that of the atmosphere. ${ }^{10}$ Savery's engine in order to lift water from mines required a steam pressure greater than that which the boilers built in his time were capable of withstanding. Increasing the steam pressure would cause Savery's engine to explode.

The next significant step in the evolution of the steam engine came when James Watt was asked to repair a model of a Newcomen engine. He studied the model and realized there was a great wastage of steam resulting from the heating of the cylinder and its cooling at each stroke. In 1765 it occurred to Watt that if a separate vessel containing a vacuum was connected to the cylinder the steam would rush into the separate vessel and could be condensed without cooling the cylinder. The separate vessel, commonly called the separate condenser, was patented in 1769 and the patent was later extended by Parliament for an extra 25 years. The partnership of Boulton and Watt was formed in 1773, trials were made and the new engine was found to have extra power and to use one quarter of the fuel of the Newcomen engine. ${ }^{11}$ Sales were soon being made to mine owners around Great Britain and Europe.

However for the Watt engine to become truly revolutionary it had to be capable of rotary motion which would allow it to drive all kinds of machinery. Experiments had been made to get rotary motion out of Newcomen engines with some limited success. ${ }^{12}$ Watt was eventually able to create a rotary engine although it required many changes in mechanism; steam was required to act on both sides of the piston and new mechanisms were invented to connect the beam to a rod to turn a shaft

\footnotetext{
${ }^{7}$ Burstall, Aubrey F. (1963) A History of Mechanical Engineering, Faber \& Faber: London Buxton 191

${ }^{8}$ Rolt, L T C (1963) Thomas Newcomen, David and Charles: Dawlish, London 65

${ }^{9}$ Dickinson, H W (1963) A Short History of the Steam Engine, Cass: London 51

${ }^{10}$ Ibid., 29

${ }^{11}$ Ibid., 74

${ }^{12}$ Ibid., 64-65
} 
which gave the rotary motion. ${ }^{13}$ The first rotary engine was created in 1783 and by 1787 the design was standardized. This ensured the applications of the steam engine were greatly increased and in its use in the textile industry the rotary steam engine was to become the driving force of the industrial revolution.

A further improvement initiated by James Watt involved the use of expanding steam. In the early Watt engines steam was admitted throughout the whole fore-stroke and energy was wasted when steam, still under pressure at the end of the stroke, left the cylinder and entered the condenser. To solve this problem Watt stopped the admission of steam into the cylinder when the piston had made only part of its stroke, the rest of the stroke being performed by the steam expanding from boiler pressure to the low pressure of the condenser. This resulted in better fuel economy for the engine. The Cornish beam engines developed by Richard Trevithick after 1812 were similar to Watt engines but used steam at a much higher pressure (40lbs per square inch rather than 5) than was used in the Watt engines. This enabled a much earlier cut off for the admission of steam into the cylinder at about one ninth of the stroke so allowing a still greater expansion of the steam.

Yet another development concerned the invention of a compound engine with two cylinders by Jonathan Hornblow in 1781 which was developed by Arthur Woolf in 1803 . Steam first enters a small cylinder, where it expands from boiler high pressure to an intermediate pressure and then enters a larger cylinder, where it expands down to condenser pressure while performing work against a piston in each cylinder. This gives a better uniform motion and reduces loss of energy caused by the alternative heating and cooling of the cylinder walls. table below.

The improvements made to the steam engine increased its thermal efficiency as shown by the

\begin{tabular}{|l|l|l|}
\hline Date & Type & Thermal efficiency (percent) \\
\hline & & \\
\hline 1750 & Newcomen & 0.5 \\
\hline 1767 & Modified by Smeaton & 0.8 \\
\hline 1774 & Further modified by Smeaton & 1.4 \\
\hline 1775 & Watt & 2.7 \\
\hline 1792 & Watt Expansive & 4.5 \\
\hline 1816 & Woolf Compound & 7.5 \\
\hline 1834 & Trevithick Cornish & 17.0 \\
\hline
\end{tabular}

As the steam engine improved its uses grew from pumping water out of mines, to driving machinery in factories, to its use in transport such as railways and steam ships.

The social and cultural effects of the steam engine were immense. The steam engine was to be the driving force of the Industrial Revolution. It was to become the main power source for the factories that arose initially in England and eventually in the rest of Europe and the USA during the 19th century. It was to result in a massive transfer of labour from working in agriculture to working in manufacturing and industry. Steam engines were to power textile mills in England and were later used for digging and moving coal, and for smelting and manufacturing iron and steel, and in the printing industry. Steam power was also used in agriculture to power threshing machines.

\footnotetext{
${ }^{13}$ Ibid., 80

${ }^{14}$ Thirring, Hans (1958) Energy for Man, Indiana University Press: Bloomington 51

${ }^{15}$ Ibid., 51-52.

${ }^{16}$ Burstall, Aubrey F. (1963) A History of Mechanical Engineering, Faber \& Faber: London Buxton, 279
} 
The use of steam power in industry was to result in a massive expansion in the size of towns and cities, so that the majority of the population of industrial states were to live in an urban environment. Conditions in the rapidly growing cities for the workers and the poor were often crowded and filthy leading to the growth of trade unions and political ideas such as socialism and communism. Living standards of the urban poor in industrial societies were soon to improve and democracy was to become the principal political system for industrial states replacing more or less absolute monarchy which had been the principal political system of societies based on agriculture.

Steam power was also used in transport, especially in railways and in shipping. Railways spread throughout Europe and the United States in the 19th century leading to a much more mobile population and to the more efficient movement of trade goods. Steam ships were to lead to a massive expansion in international trade in the 19th century and to vast migrations of people especially from Europe to America. Improved transport was to help make famine, often a problem in agricultural societies, a rarity in industrial societies, likely to happen only in unusual situations such as war time.

There were a range of factors that influenced the development of the steam engine. A real and significant need was a major factor in the development of steam power. The problem of water getting into mines would have existed all over Europe, but was particularly bad in Great Britain which had the largest mining industry in Europe. By 1650 British coal mines were producing five times as much coal as the rest of the world and mines were becoming deeper and extending further underground. ${ }^{17}$ Output is estimated to have expanded from 200,000 tons in the 1550 's to nearly 3 million tons in $1700 .^{18}$ In these circumstances, the need to get water out of mines was largely a British problem so that it is not surprising that the British were the people to solve it. That, this was a considerable problem can be seen in that one in seven of the patents granted between 1561-1642, related to the need to get water out of mines. This need was obviously not an ultimate need, but the coal was used either for the ultimate need of providing warmth or in processes that eventually related to an ultimate need.

Considerable scientific progress had been made in the years preceding the invention of the steam engine. The principles of vacuums, atmospheric pressure and the properties of gases such as steam had been discovered by Boyle, Torricelli and von Guericke immediately before the invention of the steam engine. We do not know the exact process by which Newcomen invented his engine, but it seems hardly possible that he could have invented the engine without a knowledge of the properties of vacuums, atmospheric pressure and of gases. Papin certainly knew of Boyle's Law and of the properties of gases, vacuums and atmospheric pressure. From 1675-1679 he worked as Boyle's assistant and he was an expert designer of air pumps and air pump experiments. Air Pumps were used to create vacuums and to control the air pressure within a container. Air pumps were a key element in the discovery of the properties of gases, atmospheric pressure and vacuums. The principle that the heating of gases under a piston would force the piston to rise, is not something that can be obtained by simple observation. It could only be obtained by experiment. Watt and the other improvers of the steam engine would hardly have attempted to use a gas to lift a piston unless they knew that gases expand when heated. It is this vital bit of knowledge, unknown before the propagation of Boyle's Law in the 17th century that allowed the invention of the post Newcomen engine. James Watt had considerable scientific knowledge and it was his knowledge of Black's theory of latent heat that lead to his invention of the separate condenser.

One of the principal difficulties facing those who tried to develop steam power was the low quality of the materials they had to work with. As Dickinson said concerning the problems Newcomen would have faced "chains would break, pipes would burst, leather would tear away and incrustation

\footnotetext{
${ }^{17}$ Lewis, Brian (1971) Coal Mining in the Eighteenth and Nineteenth Centuries, Longman Group Ltd: London 10.

${ }^{18}$ Neil (1978) The Economic Development of the British Coal Industry, Batsford Academic: London, 11
} 
would form in the boiler and on the interior of the cylinder." ${ }^{19}$ Dickinson also attributes the failure of Savery's engine to imperfections of workmanship and unreliability of materials and in particular to the inability of tradesmen at that time to make boilers able to withstand a substantial amount of steam pressure. ${ }^{20}$ It is much more likely that these sort of technical problems and their lack of knowledge of how to create a vacuum stopped the Romans developing a steam engine, than slavery did. By the end of the 18th century the situation had improved greatly with Watts engines having a much higher standard of workmanship in the making of its valve, valve gear and in the boring of its cylinders. Engine building had begun to move out of the hands of millwrights and into the hands of specialist manufacturers. Dickinson considered new techniques for the boring of cylinders, introduced by John Wilkinson, were vital to the success of Watt's engine. ${ }^{22}$ Equally the high pressure engines produced in the first half of the 19th century were dependent upon improved workmanship and materials to stop boiler explosions. It seems clear that progress in the metal working trades was a vital factor in the development of the steam engine without which the steam engine would not have been developed or would have remained a crude inefficient device restricted to pumping water out of mines and would not have become a key factor in the industrial revolution.

A further point that emerges from our study is the move from simplicity to complexity in engine development. When John Smeaton, who did so much to improve the Newcomen engine, first saw a Watt engine he considered it a pretty engine, but too complicated. ${ }^{23}$ The move to greater complexity involved adding things to the engine such as the separate condenser, a second cylinder, expanding steam and rotary motion to improve its performance. Such progress had to be made one step at a time and in a particular order as the problems which were intended to be solved by adding to the complexity of the engine would only become apparent at an earlier stage of the engines development and the solutions were sometimes dependent upon newly acquired knowledge which arose only from practical experience in using the engines. Only when these problems became apparent was it possible to attempt to solve them, so the steam engine grew from a simple idea to a more complicated engine as people attempted to improve it.

The social conditions necessary for the development of the steam engine were a society where the free communication of ideas was allowed and encouraged. The steam engine was not invented by any one man and it was necessary for all those involved in its invention to be able to freely communicate their ideas and inventions. It was an invention that had its origins in antiquity and was actually developed over a period of about a 100 years by a number of separate individuals. The steam engine was invented both due to individual brilliance on the part of those who contributed to it but also due to a considerable diffusion of knowledge between those contributors. Certainly James Watt developed his engine from a model of a Newcomen engine. Another improvement Watt made to the steam engine to give it rotary motion was a conical pendulum centrifugal governor which ensured the steady motion of the engine, even when the load on it varied. The same system was used in flour mills to regulate the speed of mill stones.

A crucial point is that those who worked on steam engines published accounts of their work. That is how we know of their work and that is how they would have learnt of each other's work. Giambattista della Porta published his work in his Spiritali in 1606, the Marquis of Worchester published his in his A century of the names and scantlings of the Marquis of Worchester's inventions; Sir Samuel Morland in a chapter of a book he wrote, the chapter being called The principles of the new force of fire invented by Chevalier Morland ...; Thomas Savery in a book called The Miners Friend; while Denis Papin published his work in Philosophical Investigations. The publishing of the

\footnotetext{
${ }^{19}$ Dickinson, H W (1963) A Short History of the Steam Engine, Cass: London, 35

${ }^{20}$ Ibid., 35.

${ }^{21}$ Rolt, L T C (1963) Thomas Newcomen, David and Charles: Dawlish, London 135

${ }^{22}$ Dickinson, H W (1963) A Short History of the Steam Engine, Cass: London 74.

${ }^{23}$ Rolt, L T C (1963) Thomas Newcomen, David and Charles: Dawlish, London 134

${ }^{24}$ Dickinson, H W (1963) A Short History of the Steam Engine, Cass: London 83.
} 
work done by these people, played a crucial role in the diffusion of knowledge of steam power and allowed each person, to build on the work of his predecessors. It should be added that in many cases there was confirmation of the work of these men from other sources such as other people's books and diaries, British government state papers and the granting of Letters Patent. That the knowledge of the progress of steam power was reasonably widely known, at least within the circles of those interested in it, was shown by a poem written by Henry Beighton known as the Prize Enigma in which Beighton recites the history of the work done on steam power by the Marquis of Worchester, Savery and Newcomen. That Beighton apparently knew both Savery and Newcomen and knew of Worchester's work strongly suggests that Newcomen and Savery would have known of each other's work and that of the Marquis of Worchester's. Further elements in the diffusion of knowledge of steam power was the presence of organizations such as the Royal Society and that the work was to some extent concentrated in particular areas such as London, where the Royal Society and the English court were located, and Devon.

There were a number of conditions necessary for the invention of the steam engine. A vital one was the presence of a need, initially that of how to get water out of mines and later how to drive the new machinery that was being produced as part of the industrial revolution. But needs are common and they are not always met. The reasons why those needs were met was due to the scientific progress that was going on in 16th and 17th century Europe concerning the knowledge of atmospheric pressure, how to create vacuums and of the properties of gases. Allied to this scientific progress was a belief in Europe at the time that progress could be made and problems could be solved. The inventors at the time such as Papin, Newcomen and Watt applied the scientific knowledge to solving the problems that existed and after long periods of trial and error were able to produce a working steam engine (Newcomen's) which was then improved to become Watt's engine. Crucial to the progress made by the inventors was the diffusion of scientific and engineering knowledge which enabled them to build on each other's work. The earlier development of printing was important to the diffusion process and the role of organizations such as the Royal Society was also important. Poor quality materials were a great problem facing those trying to construct a workable steam engine. Once this difficulty became apparent at the start of the 18th century with the Savery and Newcomen engines, work was done to improve the materials so that Watt's engine, which required better materials was able to be built.

Bibliography:

Burstall, Aubrey F. (1963) A History of Mechanical Engineering, Faber \& Faber: London Buxton, Dickinson, H W (1963) A Short History of the Steam Engine, Cass: London

Lewis, Brian (1971) Coal Mining in the Eighteenth and Nineteenth Centuries, Longman Group Ltd: London

Lord, John (1923) Capital and Steam Power, P S King \& Son Ltd: London

Neil (1978) The Economic Development of the British Coal Industry, Batsford Academic: London

Roll, Sir Eric (1930) An Early Experiment in Industrial Organisation, Augustus M Kelly Publishers:

New York

Rolt, L T C (1963) Thomas Newcomen, David and Charles: Dawlish, London Thirring, Hans (1958) Energy for Man, Indiana University Press: Bloomington

Tunzelmann, G N (1978) Steam Power and British Industrialisation to 1860, Clarendon Press: Oxford Watkins, George (1978) The Steam Engine in Industry Vols 1 \& 2, Moorland Publishing: Derbyshire, England 